\title{
学会賞受賞講演
}

\section{Studies on Viscoelastic Properties of Macromolecules Using Some Model Polymers}

by

\author{
Mitsuru NAGASAWA \\ Toyota Technological Institute, \\ Hisakata, Tenpaku-ku, Nagoya 468, Japan
}

In reviewing the papers published by the author and his coworkers, the discussion was focused on two topics; entaglements of linear polymers in concentrated solutions and steady-state compliance of branched polymers.

1) The intersegmental interaction working as entanglements in polymer solutions is different in different solvents as well as in different phenomena. The difference can well be observed by determining the critical degree of coil-overlapping in the scaling or its corresponding plot, at which entanglements begin to appear. The entanglement formation was found to become more difficult in the order of osmotic pressure, viscosity and steady-state compliance. And, the hydrodynamic entanglement for viscosity is stronger in poor solvents than in good solvents. Moreover, the shear rate dependences of steady-flow viscosity and steady-state compliance at different polymer concentrations form universal curves if they are reduced by a factor of $1 / C^{2}$. That is, the effect of increasing shear rate is equivalent to that of decreasing polymer concentration. This means that the main effect of increasing shear rate would be in decreasing the effective entanglement density. An analysis of transient viscoelastic phenomena such as stressovershoot was presented based on this network rupture model. From these experimental results, it was pointed out that the solution viscosity of a linear polymer in poor solvents would be, in general, higher than in good solvents, whereas it is well known to be opposite in dilute solutions.

2) As molecular weight $M$ of a polymer is increased and/or as polymer concentration $C$ is increased, the steady-state compliance $J_{\mathrm{e}}$ of both linear and branched (nearly star-shaped) polymers transfer from the dilute solution region $\left(J_{\mathrm{e}} \propto M / C\right)$ to the quasinetwork region $\left(J_{\mathrm{e}} \propto M^{0} / C^{2}\right)$ at a critical value of $C M$. In the dilute solution region, $J_{\mathrm{e}}$ of star-shaped polymers is lower than that of the corresponding linear polymers having the same molecular weight, whereas it is opposite in the undiluted state. From comparison between polymer concentration dependences of branched and linear polymers it was pointed out that the critical value of $C M$ for star-shaped polymers is much higher than that for linear polymers, in contrast to the fact that the critical degree of coil-overlapping for viscosity is not much affected by branching. Consequently, $J_{\mathrm{e}}$ of star-shaped polymers becomes higher than that of the corresponding linear polymers at the undiluted state.

Key words: Model Polymer / Branched Polymer / Entanglement / Viscoelasticity / Steady-State Compliance

\section{モデル高分子を用いた高分子粘弾性の研究}

$$
\text { 永澤満* }
$$

(原稿受理：1989年 8 月30日)

\section{1. はじめに}

現在では高分子物性研究に於けるモデル高分子の重要性は十分

* 豊田工業大学, $\bar{\top} 468$ 名古屋市天白区久方 $2-12-1$
に認められていると思うが，昭和 38 年に藤本輝雄氏（現長岡技科

大）と共にアニオン重合法によって分子量分布の狭い，いわゆる 単分散高分子の合成をはじめた頃は必ずしあそうではなかった。 その後, 藤本, 北野利明 (現ポリプラスチックス), 松下裕秀氏 
らが名古屋大工学部に於て合成したモデル高分子はいろいろある が，狭い分子量分布を持っていて，その時点で他と比較して特徽 があったと思われるモデル高分子をあげてみよう.

\section{Poly $(\alpha$-methylstyrene $)[\mathbf{P}(\alpha \mathbf{M S})]^{1)}$}

Bywater らむ溶液論研究用に用いたが，分子量 700 万までを力 バーし，いわゆる単分散ポリスチレンと比較しても，はるかに狭 い分子量分布を持つ点で特徵的である.

2. Poly(styrene) $[\mathrm{PS}]$ with $M_{w} \gtrsim 10^{9}$ ८)

1,000 万以上の分子量を持ち，分子量分布の狭いポリスチレン は高分子物性分子論の領域を挔げた。

\section{Poly (t-butylcrotonate) $[\mathbf{P T B C}]^{3), 4)}$}

PTBC の分子鎖の stiffness はそれほどではないが，分子量分 布が狭いと言う特徽がある.フィルムは PMMA と同程度の透明 性を持ち，しかも $180^{\circ} \mathrm{C}$ 以下ならば長期使用に耐えるであろう.

\section{Polyelectrolytes ${ }^{5), 6)}$}

アニオン重合法にてt-ブチルアクリレートを重合し，それを加 水分解して分子量分布の狭いポリアクリル酸を合成した。 また， カチオン型の poly (4-vinylbenzyltrimethylammonium chloride) あかなり狭い分子量分布を持つ.

\section{Star-shaped poly(styrene) with long branches ${ }^{7)}$}

名工大浅見教授の提案を基にして三官能性アニオン重合開始剤 を用いて，1本の枝の分子量 100 万を超える星型高分子を合成し た.

\section{Comb-shaped poly(styrene) with long branches ${ }^{8)}$}

乙の試料は幹, 枝分子共に狭い分子量分布を持っているが， 1 本当たりの枝の数に分布がある. 枝の分子量が幹の分子量に比し てかなり大きいので星型に近い.

\section{Tri-block copolymer ${ }^{9), 10)}$}

PS-poly(isoprene)-poly[(4-vinylbenzyl)dimethylamine] 各成 分の分子量が変わると，いろいろ興味深いモルフォロジーを示す。 てのポリマーは藤本氏が長岡技大に移ってから, 三成分五元ブロ ック共重合体へと発展させ，はじめて荷電モザイク膜を合成し注 目された ${ }^{11)}$.

\section{Tri-block copolymer containing a deuterated block ${ }^{12)}$} $\sim 15)$

d-スチレンモノマ (d8) の精製に成功して, PS(h8)-PS(d8)PS(h8), PS(h8)-PS(d8)-poly(2-vinylpyridine) を合成し, 中性 子小角散乱実験化用いつつある.

そのすべてをレオロジー研究に用いたわけではないが，てれら の試料を用いて行った研究結果のいくつかを「銧状高分子間のか らみ」と「分岐高分子の粘弾性」の形にまとめてみよう。それぞ れ研究の中心梳なて努力した諸氏の名前をあげたいが，割愛さ せていただくことにしょう。

\section{2. 鎖状高分子間のからみ}

鎖状高分子希薄溶液の物性は，高分子鎖コイルの慣性半径之高 分子コイル間の相互作用によってほぼ決まる。熱力学的性質の場 合には, 高分子コイル間相互作用は第 2 ビリアル係数であり, 粘 性の場合には Huggins 定数 $k^{\prime}$ である、濃厚溶液あるいは高分 子融体中では高分子コイルは十分重なり合い，分子鎖はからみ合 っている，そして，高分子コイル内のセグメント分布は，ほぼ非
摂動状態 (unperturbed state) にあることあわかっている. 従っ て，からみ域にある高分子濃厚溶液，あるいはメルトの物性は平 均からみ点間距離, 即ちからみ点間分子量とからみ点として働く セグメント間相互作用によってほぼ決定されると考えている.

高分子濃度が一定の場合には，セグメントが空間的に衝突する 確率, あるいはある距離内に近ずく確率は分子量に無関係に一定 である。しかし，どの程度近づいたらからみ点として働くかは， 当然観測する物性によって違う. 同じ濃度に於て有効からみ点間 分子量を測定すれば，現象の違いによるセグメント間相互作用の 差を観測することが出来るが，高分子鎖コイルが重なりはじめて， 希薄溶液からからみ領域へと移行する点を決定すると, その違い を明確に観察することが出来る.

浸透圧や粘性係数などの濃度依存性が, 高分子コイル間相互作 用で決まる希薄溶液之高分子コイルが十分重なりあって，からみ 点間分子量によってその物性が決まる濃厚溶液の間に, 物性が 2 つの高分子コイルの重なりあいの程度 (degree of coil overlapping）で決まる準希薄溶液領域があることが, de Gennes ら ${ }^{16)}$ 指摘にはじまる近年の研究によって明らかになった ${ }^{17)}$. Table I 飞希薄溶液 $(D)$, 準希薄溶液 $(S)$, 濃厚溶液 $(C)$ の三領域におけ る浸透圧 $\pi$, 粘性係数 $\eta$, 定常状態コンプライアンス $J_{\mathrm{e}}$ の高分 子の分子量 $M$, 濃度 $C$ 依存性を比較しておく。 $C$-領域には融体, アモルファス固体す含まれる。私は $J_{\mathrm{e}}$ を論ずる場合, 乙の領域 をしばしば “からみ域”とも呼んでいる，弾性率の逆数に相当す る定常状態コンプライアンス $J_{\mathrm{e}}$ の場合には, 準希薄溶液領域は 実験可能な分子量, 濃度範囲内では観測されなくて, D-領域か ら直接 $C$-領域（からみ域）飞移行する. Table I の予測に従っ

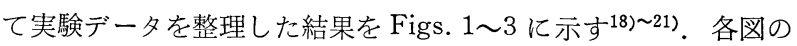
[A]はいずれも通常の濃度依存性のプロットであるが,〔B]は Table I の考え方でプロットしている. Figs. 1-[B] 及び2-[B] の不連続点は, からみが発生する高分子コイルの重なり度を示し ている. 粘性係数の場合には, 準希薄溶液領域は低分子量試料を 用いた実験でははっきりしないので，Fig. 2-[B]には[A]之は 別に特に高分子量試料を用いて行った実験データを示してある. 希薄溶液加準希溥溶液へ移行する境界の $\left(C / C^{*}\right)$ は， $\pi$ の場 合には $\left(C / C^{*}\right) \simeq 2, \eta$ の場合には $\left(C / C^{*}\right) \simeq 10$ であって, 高分 子鎖コイル間の相互作用がからみ点として働くのは, 熱力学的相 互作用の場合には容易に起こるが, 流体力学的相互作用の場合に はそれよりはるかに起とりにくい．

Fig. 3-[A]，[B]の $J_{\mathrm{e}}$ に関するプロットでは Table I の $J_{\mathrm{eR}}$ を用いていないが，同じ意味をもっているととは容易に理解出来 るであろう. Fig. 3-[A]の右側の傾斜 -2 の直線がからみ域で あって分子量に無関係であり, 左側の分子量によって变わる領域 が $D$-領域である. Fig. 3-[B]のD-領域とからみ域では, 傾斜 が -1 から -2 へと変化するので, その境界は容易に決定出

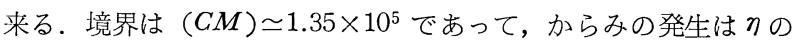
場合よりあはるか信い濃度で起とり, その濃度では高分子コイ ルはすでに十分に重なり合っている. 高分子量 PSを用いて, 更 に詳細にからみ域における $J_{\mathrm{e}}$ の濃度依存性を検討した結果を Fig. 4 亿示す ${ }^{21)}$. 白丸は良溶媒, 黒丸は準 $\theta$ 溶媒中のデータであ るが, この傾斜を詳細に検討した結果, $S$-領域の存在を認める ことが出来なかった．とにかく異なる高分子鎖コイル中のセグメ ント間相互作用が弾性を示す結合点として働くのは，セグメント 
Table I. Molecular weight $(M)$ and concentration dependences of osmotic pressure $(\pi)$, viscosity $(\eta)$, and steady-state compliance $\left(J_{\mathrm{e}}\right)$.

( $D, S$, and $C$ represent dilute, semi-dilute, and concentrated solutions, respectively)

\begin{tabular}{|c|c|c|c|}
\hline & $\pi$ & $\eta$ & $J_{\mathrm{e}}$ \\
\hline Reduced form & $\pi_{\mathrm{R}} \equiv \pi M / C R T$ & $\eta_{\mathrm{R}^{0}}^{0} \equiv \eta_{\mathrm{sp}} / C[\eta]$ & $J_{\mathrm{er}} \equiv \frac{J_{\mathrm{e}} C R T}{M}\left[\frac{\eta}{\left(\eta-\eta_{\mathrm{s}}\right)}\right]^{2}$ \\
\hline$D$ & $\pi_{\mathrm{R}}=1+1.12\left(C / C^{*}\right)$ & $\eta_{\mathrm{R}^{0}}=1+k^{\prime}\left(C / C^{*}\right)$ & $J_{\mathrm{eR}}=$ const. \\
\hline$S$ & $\pi_{\mathrm{R}} \propto\left(C / C^{*}\right)^{1 /(3 \nu-1)}$ & $\begin{array}{l}\eta_{\mathrm{R}}^{0} \propto\left(C / C^{*}\right)\left(\frac{a+1-3 v^{\prime}}{3 v-1}\right) \\
\eta_{\mathrm{sp}}{ }^{0} / M^{\mathrm{a}} \propto C^{\mathrm{a} /(3 \nu-1)}\end{array}$ & $\left\{\begin{array}{l}J_{\mathrm{eR}} \propto\left(C / C^{*}\right)^{1 /(1-3 \nu)} \\
J_{\mathrm{e}} \propto C^{3 \nu /(1-3 \nu)}\end{array}\right\}^{*}$ \\
\hline C & $\begin{array}{c}\text { Flory \& Huggins' theory } \\
\text { (independent of } M \text { ) }\end{array}$ & $\begin{array}{c}\eta_{\mathrm{sp}}{ }^{0} / M^{\mathrm{a}} \propto C^{\alpha} \\
(\alpha \text { increases with } G)\end{array}$ & $\begin{array}{l}J_{\mathrm{e}} \propto 1 / C^{2} \\
(\text { independent of } M \text { ) }\end{array}$ \\
\hline
\end{tabular}

1) All parameters are those at $\dot{\gamma} \rightarrow 0$

2) $C^{*}=3 M / 4 \pi\left\langle S^{2}\right\rangle^{3 / 2} N_{\mathrm{A}}$

3) $\nu:\left\langle S^{2}\right\rangle \propto M^{2 \nu}$

4) $a: \eta^{0} \propto M^{\mathrm{a}}$ (undiluted state, in bulk)

5) $C / C^{*} \propto C[\eta]$

6) $*$ : have not been observed.

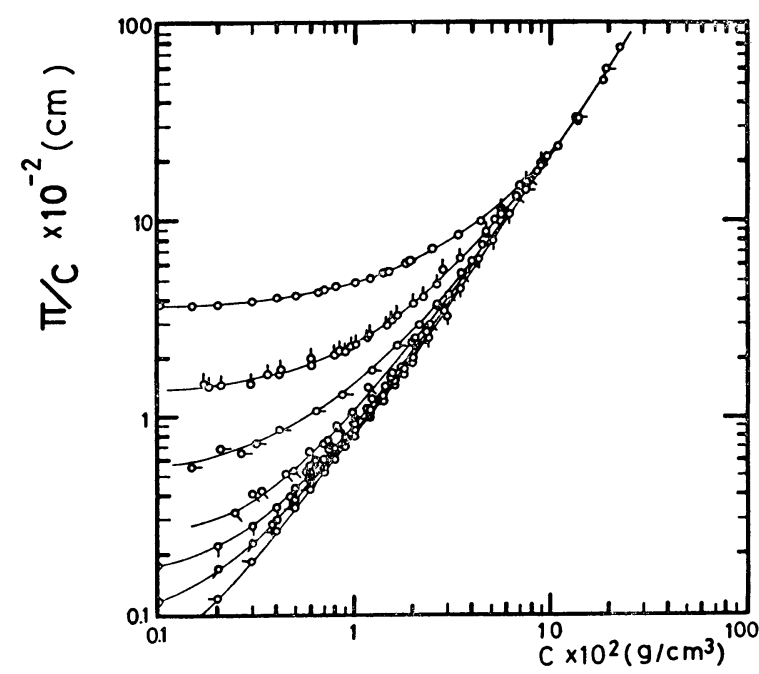

Fig. 1-A Polymer concentration dependence of osmotic pressure $\pi$ of $P(\alpha M S)$ in a good solvent (toluene at $\left.25^{\circ} \mathrm{C}\right) . M_{\mathrm{w}}$ of the samples are; $(-\infty) 7.47 \times 10^{6}$ (maximum), (O) $7.08 \times 10^{4}$ (minimum). (reproduced from ref. 18).

濃度がはるかに高濃度になってからである。なお，Figs. 1〜3で はポリ（ $\alpha$ ーメチルスチレン）とポリ（スチレン）の両方のデー 夕を用いているが，乙の目的のためには両者の間には殆ど差がな い之考えてよい. Fig. 5 亿浸透圧, 粘性係数, 定常状態コンプラ イアンスの三現象に於ける希薄, 準希薄あるいはからみ領域の境 界の違いを比較しておく ${ }^{21)}$.

からみ点の発生し易さは以上のように現象によって異なるが, 溶媒によっても異なる. Fig. 6に溶媒中のクのスケーリングプ ロットを示す. Fig. 2 と Fig. 6 の比較から溶液粘性の增加をむ たらすセグメント間相互作用は, 良溶媒中より貧溶媒中ではるか に強く, $\theta$ 溶媒中では高分子鎖コイルが重なりはじめるとすぐか

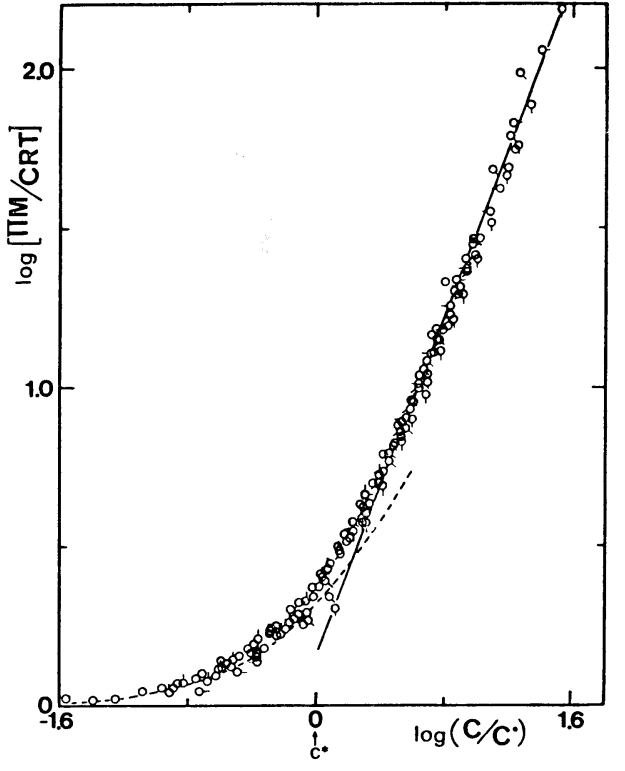

Fig. 1-B Double logarithmic plots of reduced osmotic pressure and reduced concentration, replotted from the data in Fig. 1-A. The solid line shows the predicted slope from the scaling theory. (reproduced from ref. 18)

らみが発生することがわかる19)。われわれはこれを貧溶媒中のか らみ点の強さは，良溶媒中より強いと表現する，Je場合にも貧 溶媒中の方が低濃度でからみ域に入るようであるが，クの場合程 顕著ではない22)

Figs. 7 と 8 に と $J_{\mathrm{e}}$ のずり速度 $\dot{\gamma}$ 依存性を示す（われわれは $\dot{\gamma} \rightarrow 0$ の極限の定常状態コンプライアンスに対し $J_{\mathrm{e}}$ を用い, $\dot{\gamma} に$ よって変化する領域の見かけの定常状態コンプライアンスを $J_{\mathrm{s}}$ にて表現している. また， $\dot{\gamma} \rightarrow 0$ 極限のクの值は $\eta^{0}$ にて表す). $\eta$ は字の増大と共に減少するが， $J_{\mathrm{s}}$ は逆に増大する ${ }^{22)} . J_{\mathrm{s}}$ が 


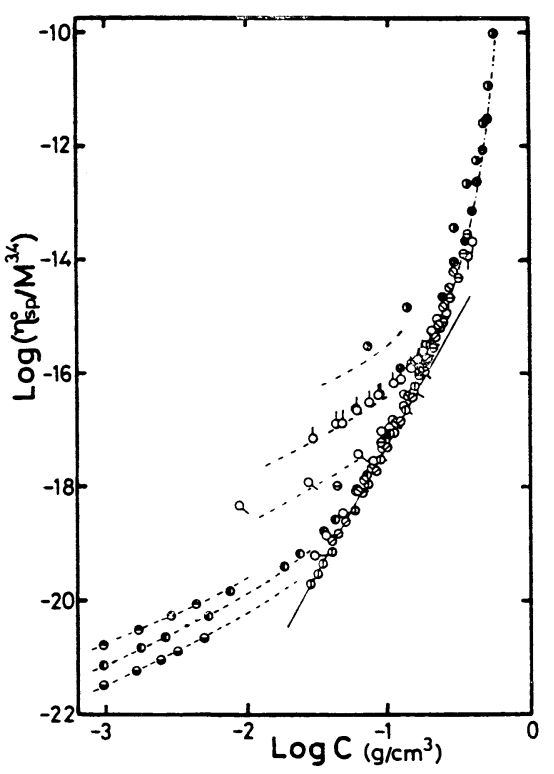

Fig. 2-A Polymer concentration dependence of $\left(\eta_{\mathrm{sp}}\right.$ \% $\left.M^{3.4}\right)$ of $\mathrm{P}(\alpha \mathrm{MS})$ in good solvents. $M_{\mathrm{w}}$ of the samples; (๑) $3.3 \times 10^{6}$ (maximum), (D) $6.0 \times 10^{4}$ (minimum). The solid line shows the prediced slope from the scaling theory. (reproduced from ref. 19)

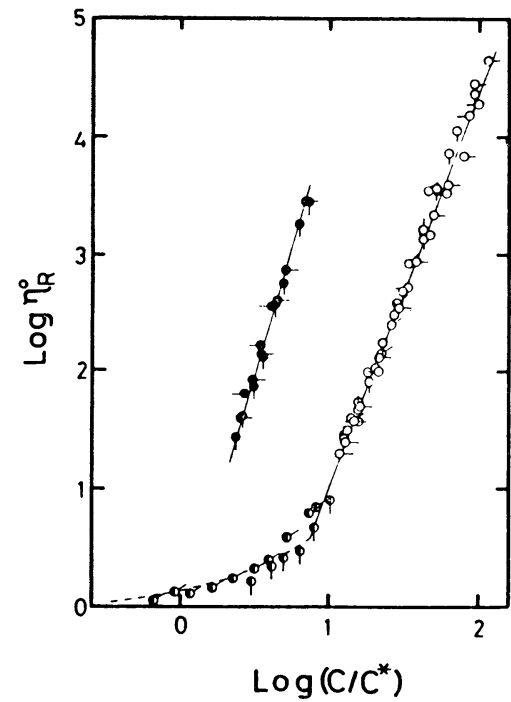

Fig. 2-B Double logarithmic plots of $\eta_{\mathrm{R}^{0}}$ vs. degree of coil overlapping $\left(C / C^{*}\right)$. The open and halffilled circles show the data in good solvents (toluene and $\alpha-\mathrm{CN}$ ), whereas the filled circles show the data in a nearly $\theta$ solvent (DOP). The solid lines show the predicted slopes from the scaling theory. $M_{\text {w }}$ of the samples (PS); (-) 20.6, (o) 8.42 , ( ( ) 4.48 , (b) 1.26 , (๔) $0.775 \times 10^{6}$. (reproduced from ref. 21 )

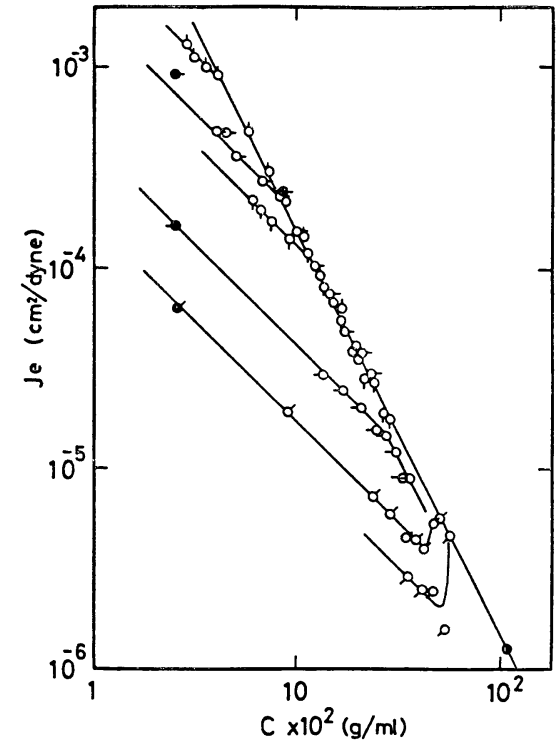

Fig. 3-A Polymer concentration dependence of $J_{\mathrm{e}}$ at the limit of zero shear rate. $M_{\mathrm{w}}$ of the samples $P(\alpha, M S)$; (b) $3.3 \times 10^{6}$ (maximum), ( o) $6.02 \times 10^{4}$ (minimum). The half-filled circle shows the datum for undiluted samples, determined from stress relaxation experiments. The other data were obtained by an Weissenberg Rheogoniometer. The solid line with slope of -2 shows the quasi-network region, while the left-hand side of the line shows the dilute solution region. (reproduced from ref. 20)

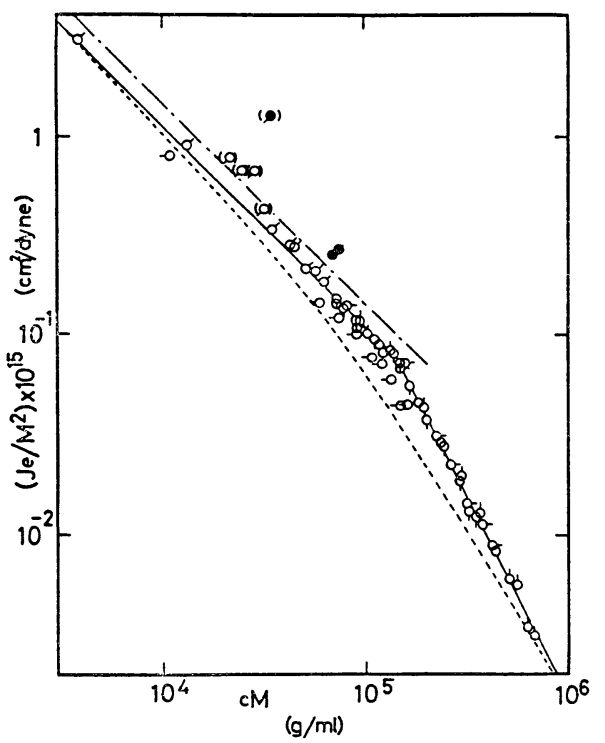

Fig. 3-B Double-logarithmic plot of $J_{\mathrm{e}} / M^{2}$ vs. $C M$, replotted from the data in Fig. 3-A. The left solid line with slope of -1 shows the dilute solution region, while the right solid line with slope of -2 shows the quasi-network region. (reproduced from ref. 20)

ての議論は省略する，濃厚溶液中のいろいろの濃度における $\log$ $\left(\eta / \eta^{0}\right)$ 及び $\log \left(J_{\mathrm{s}} / J_{\mathrm{e}}\right)$ を $\log \dot{\gamma}$ に対してプロットし，横移動 させて重㸚合わせると，移動因子 $1 / C^{2}$ を用いて Fig. 9 のように 


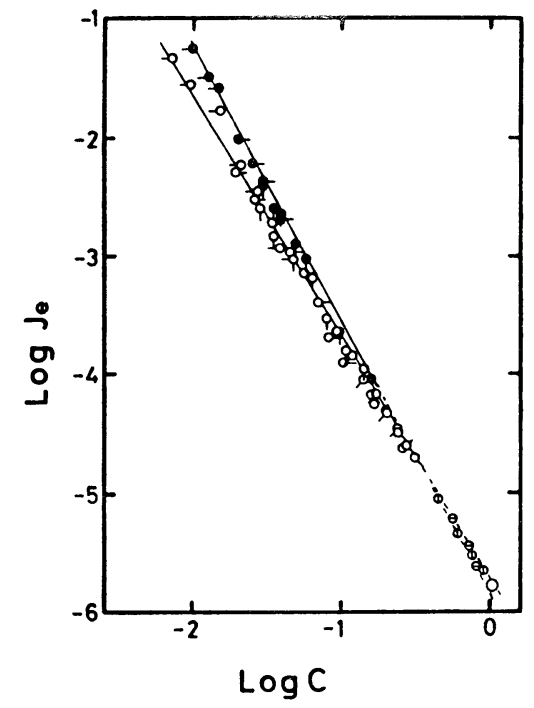

Fig. 4 Polymer concentration dependence of $J_{\mathrm{e}}$ in good and nearly $\theta$ solvents in the quasi-network region. The samples are the same as in Fig. 2-B. The open circles show the data in good solvents, whereas the filled circles show the data in a nearly $\theta$ solvent. It was concluded from comparison of these experimental slopes with the scaling theory that the semi-dilute region need not be taken into account in discussing $J_{\mathrm{e}}$. (reproduced from ref. 21)

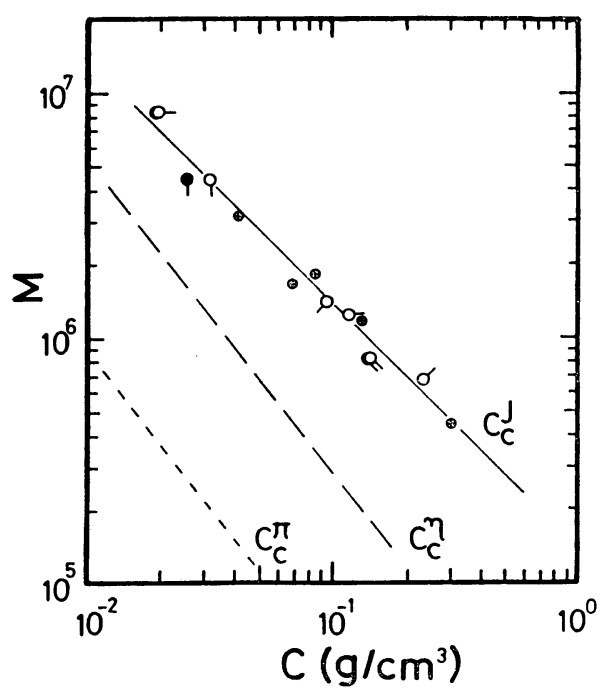

Fig. 5 Boundaries between the dilute solution region and the semi-dilute solution region or the quasinetwork region in different phenomena. The dotted line shows the boundary for osmotic pressure, broken line for viscosity and solid line for steady-state compliance. (reproduded from ref. 21)

重称合わせるととが出来る ${ }^{20)}$. 高分子濃度 $C$ の時, 高分子鎖コイ ルがある種のからみを形成する確率は $C^{2}$ に比例する，従って， Fig. 9 は粘弾性に対するずり速度の効果が高分子濃度の減少の効 果と等価であって, $\log \left(\eta / \eta^{0}\right)$ あるいは $\log \left(J_{\mathrm{s}} / J_{\mathrm{e}}\right)$ がずり速度

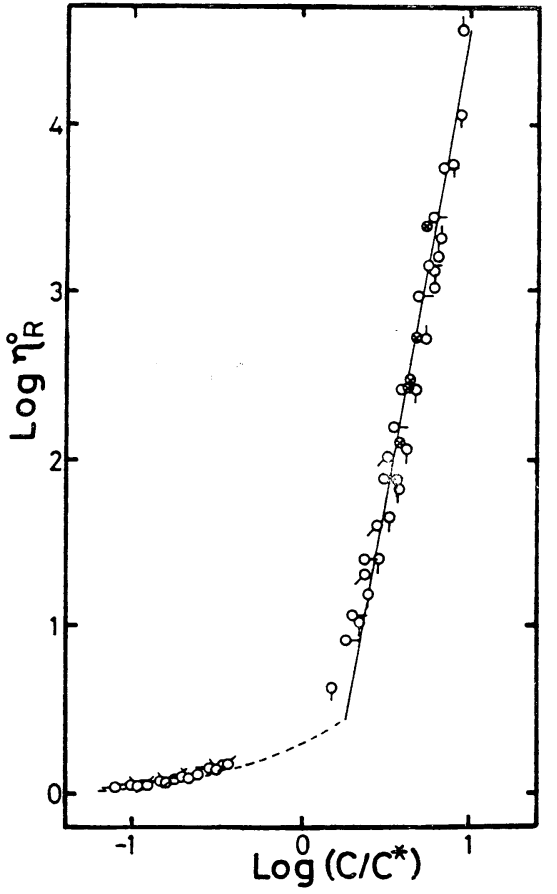

Fig. 6 The scaling plot of $\eta_{\mathrm{R}}{ }^{0}$ for the same samples as in Fig. 2-B in a nearly $\theta$ solvent. The solid line shows the slope predicted from the scaling theory. (reproduced from ref. 19)

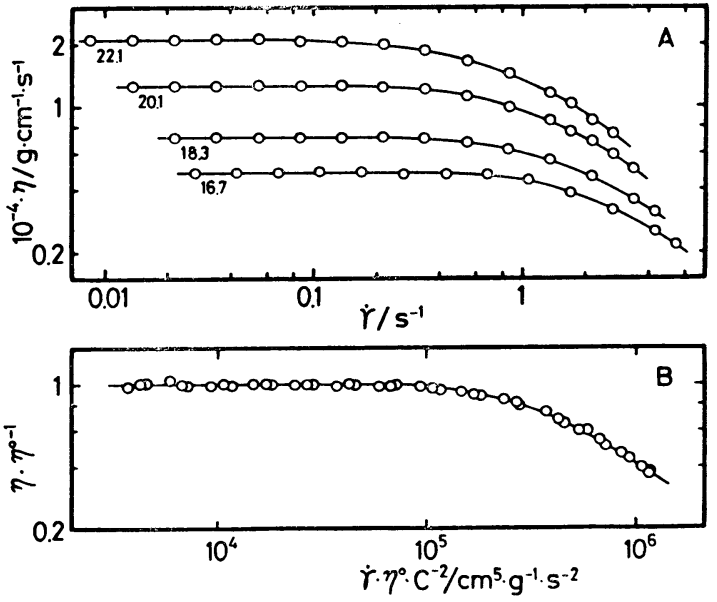

Fig. 7 Shear rate $(\dot{\gamma})$ dependence of steady-flow viscosity

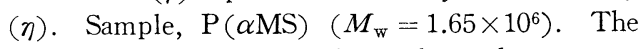
numerical figures in $A$ show the polymer concentrations $(\mathrm{g} / \mathrm{dl}) . \quad B$ shows an reduced plot obtained by superposition. The solid line in $B$ is the calculated values of Greassley. (reproduced from ref. 22)

の増加と共に減少あるいは増大するのは， $\dot{\gamma}$ 共に有効からみ点 密度が減少するためと推定出来る。ずり速度が大きくなるにつれ て有効からみ点密度が減少し, その結果粘度が減少するという考 え方の理論としては Graessley の理論がある ${ }^{24)}$ ：この理論は第一 


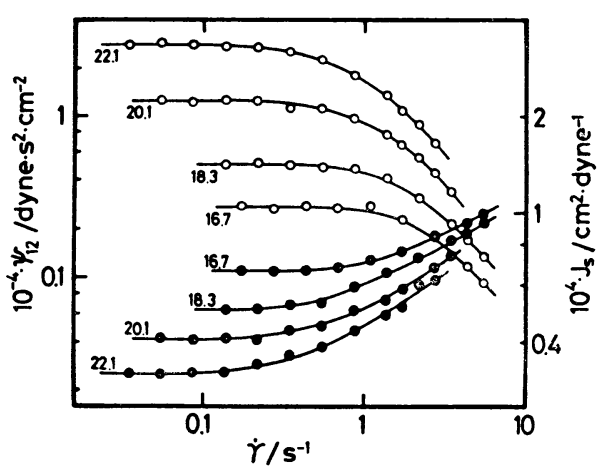

Fig. 8 Shear rate dependence of apparent steady-state compliance $\left(J_{\mathrm{s}}\right)$ (filled circles). The open circles show the first normal stress difference coefficient $\left(\psi_{12}=2 J_{\mathrm{s}} \eta^{2}\right)$. The numerical figures show poly. mer concentrations $(\mathrm{g} / \mathrm{dl})$. (reproduced from ref. 22)

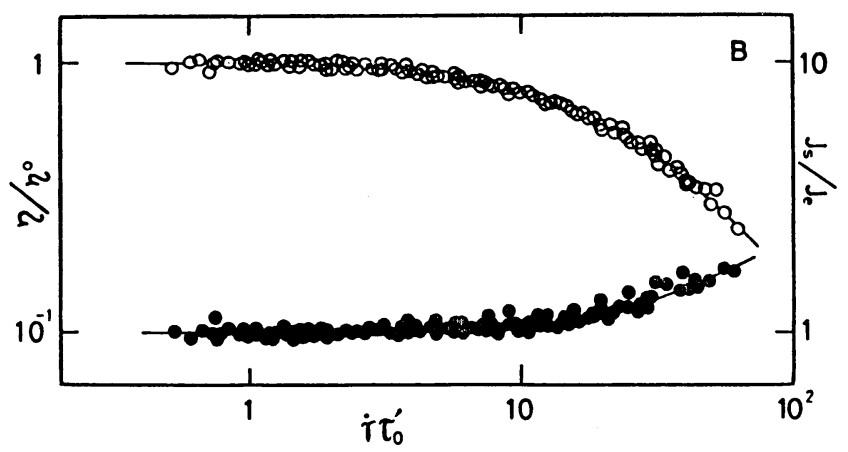

Fig. 9 Superposition of $\left(\eta / \eta^{0}\right)$ (open circles) and $\left(J_{\mathrm{s}} / J_{\mathrm{e}}\right)$ (filled circles) with respect to shear rate. Sample: $\mathrm{P}(\alpha \mathrm{MS})$ in $\alpha$-chloronaphthalene. $\tau_{0}{ }^{\prime}=\eta^{0} / C^{2} R T$. (reproduced from ref. 19)

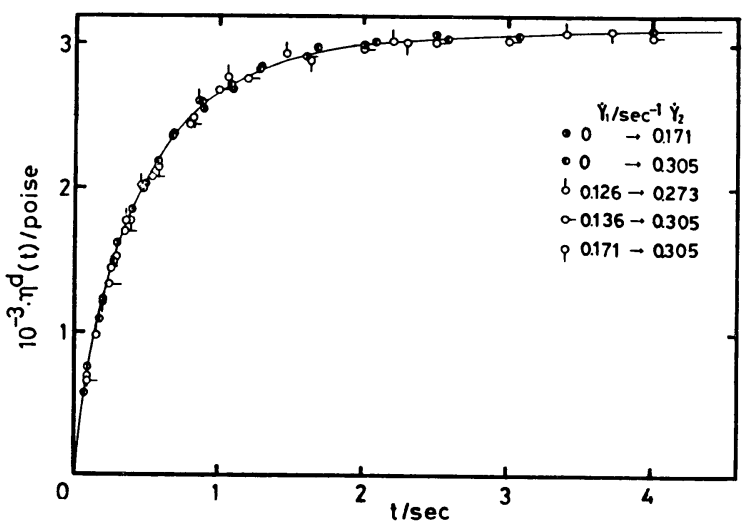

Fig. 10 Experimental transient viscosity in stress developement in the linear region. $\eta^{\mathrm{d}}(t)=\sigma^{\mathrm{d}}(t) / \dot{\gamma}, \sigma^{\mathrm{d}}(t)$ being shear stress observed after an instant change of shear rate. Half-filled circles show the data after onset of steady shear flow, while the open circles show the data after a stepwise increase of shear rate. The shear rates are denoted in the figure. Sample, PS $\left(M_{\mathrm{w}}=1.26 \times 10^{6}\right)$ in dioctyl phthalate $(13 \%)$. (reproduced from ref. 25)

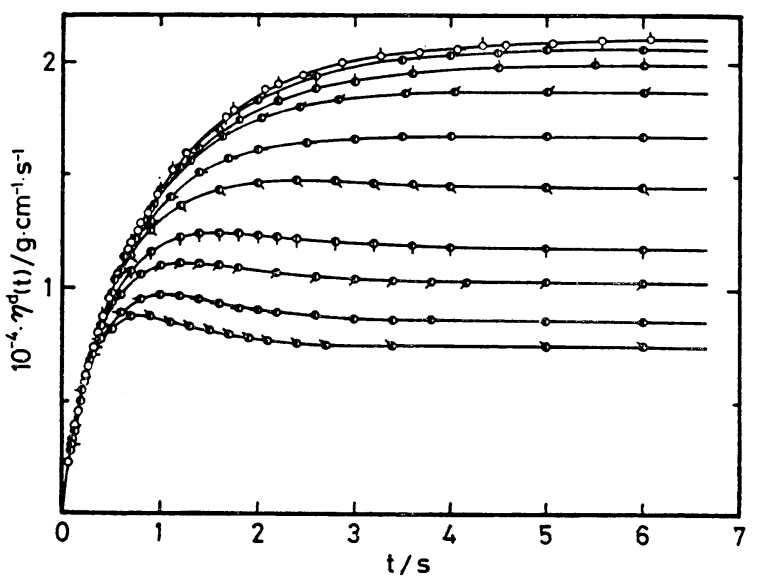

Fig. 11 Experimental transient viscosity after onset of steady shear flow at various shear rates. Sample, $\mathrm{P}(\alpha \mathrm{MS}) \quad\left(M_{\mathrm{w}}=1.65 \times 10^{6}\right)$ in $\alpha$-chloronaphthalene. Shear rate increases from top ( $\delta, 0.0216)$ to bottom $\left(2.73 \mathrm{~s}^{-1}\right)$. (reproduced from ref. 22)

法線応力差を計算出来ないから完全に満足出来るものではないが, Fig. 7-Bに見るようにクの字依存性の実験データと見事な一致 を示す.

静止している高分子溶液あるいはメルトに瞬間的にある一定の ずり速度 $\dot{\gamma}$ を加えると, ずり応力, 第一法線応力差は徐々に成長 して一定值に到達する. Fig. 1025) にはずり応力を字で割った見 かけの粘性係数 $\eta^{\mathrm{d}}(t)$ を, $\dot{\gamma}$ を加えた時点からの時間 $t$ に対し

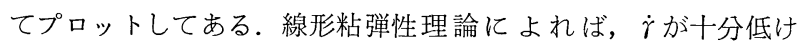
れば $\eta^{\mathrm{d}}(t)$ は次式で与えられる ${ }^{26), 27)}$.

$$
\eta_{\mathrm{d}}(t)=\int_{0}^{t} \phi(s) \mathrm{d} s
$$

ここで， $\phi(s)$ は余効関数 (after-effect function) である. $\phi(s)$ は物質によって決まる関数であるから，Fig. 10 のずり応力成長 曲線はずり速度字に無関係に一本の曲線を形成しなければならな い. また，ずり応力成長実験のみならず，ずり速度字を瞬間的に 停止させた時に観測されるずり応力緩和実験で屯，またあるずり 速度 $\dot{\gamma}_{1}$ から他のずり速度 $\dot{\gamma}_{2}$ へ変化させた時に観測する応力成長, 並びに応力緩和でも適当な処理をして式(1)の $\eta^{\mathrm{d}}(t)$ に対応する量 を計算すれば，理論的にはすべて図10と同一の曲線を示さなけれ ばならない.ずり速度字が小さければ，乙のことは実験的にも確 認出来ている ${ }^{25)}$.

しかし，ずり速度字が大きくなるにつれて $\eta^{\mathrm{d}}(t)$ は Fig. 10 の 曲線から偏移しはじめ, Fig. 1122)に示すように極大を示してか ら一定値に達する ${ }^{26), 28)}$. この現象を一般に stress overshoot と呼 んでいる， $\eta^{\mathrm{d}}(t)$ は $t$ が十分大きくなれば一定值に達するが，乙 の值の $\dot{\gamma}$ にる違いは Fig. 7 の $\log \eta$ の $\log \dot{\gamma}$ 依存性に対応して いる．乙のような非線形粘弾性現象を説明するための理論は数多 く提出されているが26)，その議諭はこてでは省略する．乙の問題 に対する私どもの考え方を Fig. 12 に示す ${ }^{29)}$. ずり速度が 0 から 字に変化すれば，高分子溶液内の有効加ら点密度は Fig. 12-A に示されるように減少する。しかし，有効からみ点密度に変化は 字が加えられた瞬間に起こるのではなく，疑似網目構造の歪みが ある一定值に達して壊れると考えてよい。乙の有効からみ点密度 


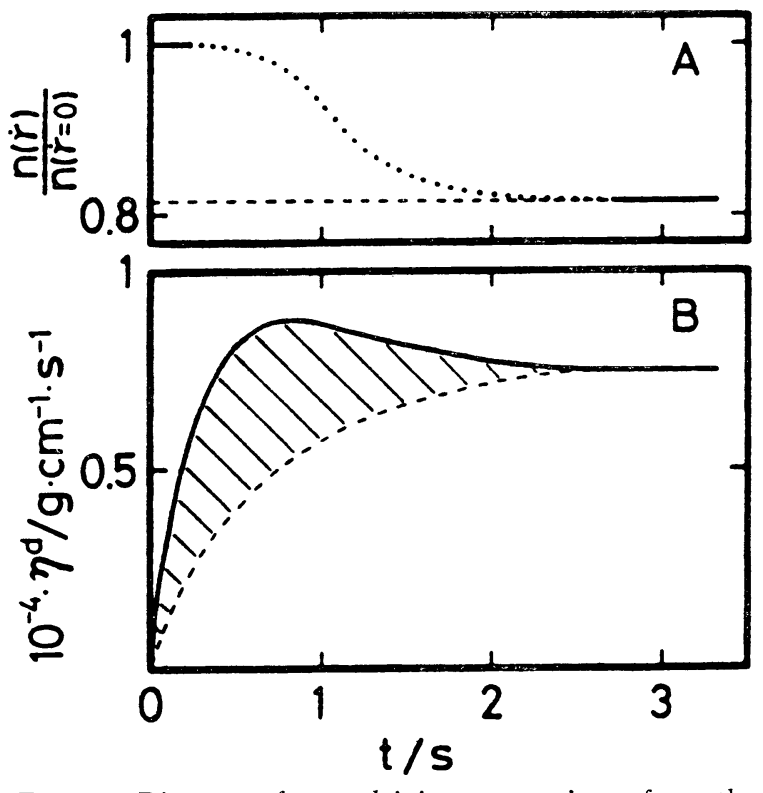

Fig. 12 Diagrams for explaining a transition from the equilibrium structure to a steady state at $\dot{\gamma}$. Sample: the same as in Fig. 11. (A) Thick solid lines denote the reduced entanglement densities at the equilibrium state and at $\dot{\gamma}=2.73$, respectively. The dotted line gives a schematic graph of change in the reduced entanglement density with time. (B) The solid line is the observed stress developement, whereas the broken line shows the stress developement in the solution which would be observed if the entanglement density were kept at constant with the value at $\dot{\gamma}=2.73 \mathrm{~s}^{-1}$. (reduced from ref. 29)

の変化に対応して, $\eta^{0}(t)$ 曲線はずり速度 0 に対応する曲線から $\dot{\gamma}$ に対応する曲線へと転移し, 結果として極大が観測される. $\dot{\gamma}=0$ に対応するからみ点密度がこわれるのは, 網目構造の丕み がある一定值に達した時と推定出来るから, $\eta^{\mathrm{d}}(t \mid \dot{\gamma}=0)$ の曲線か らの偏移が観測される時間は, 加えられるずり速度に逆比例する と推定出来る. このモデルは最近五十野らによって, ずり変形に 小さな振動を重ね, ずり変形中の有効からみ点密度の変化を测定 する実験が行われ支持された ${ }^{29-a) . ~}$

Fig. 12 のモデルが正しいとすれば Fig. 12-B の斜線部の面積 は, 有効からみ点密度を Fig. 12-A のように減少させる仕事 $\Delta W$ になる，なお，乙の斜線部の面積はずり応力成長と同時に第 一法線応力差を測定すれば，外插の仮定なしに次式によって計算 出来る ${ }^{29)}$.

$$
\Delta W=\dot{\gamma}^{2} \int_{0}^{t_{s}} \eta^{\mathrm{d}}(t) \mathrm{d} t-\left[t \eta(\dot{\gamma})-\frac{1}{2} \psi_{12}(\dot{\gamma})\right]
$$

ここで, $t_{\mathrm{s}}$ は $\eta^{\mathrm{d}}(t)$ が一定值に到達したあとの時間であり, 括 弧内はそれぞれの定常值である. また, 上述のように $\dot{\gamma}$ の変化に よる有効からみ点密度の変化は, 一応 Graessley の理諭によって 計算するととが出来るから, Fig. 12-B の斜線部の面積を求め, 減少したからみ点の数で割れば 1 個のからみ点を解くに要する仕 事を決定出来る。良溶媒中と貧溶媒中でこの值を測定し，Fig. 13 に比較する ${ }^{22}$. はじめに予測したように, 貧溶媒中の方が 1 個の からみ点を解くのにより大きな仕事を必要とする，また，はじめ

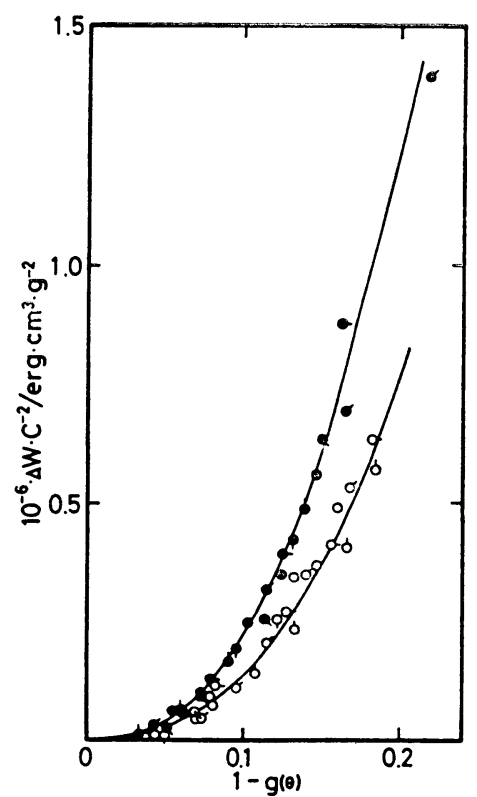

Fig. 13 The work to reduce the entanglement density. The abscissa shows the degree of entanglements dissolved. Sample: $\mathrm{P}(\alpha \mathrm{MS})\left(M_{\mathrm{w}}=1.65 \times 10^{6}\right.$ and $\left.4.40 \times 10^{5}\right)$. Open circles show the data in a good solvent ( $\alpha$-chloronaphthalene), whereas filled circles show the data in a poor solvent ( $n$-butylbenzylphthalate). (reproduced from ref. 22)

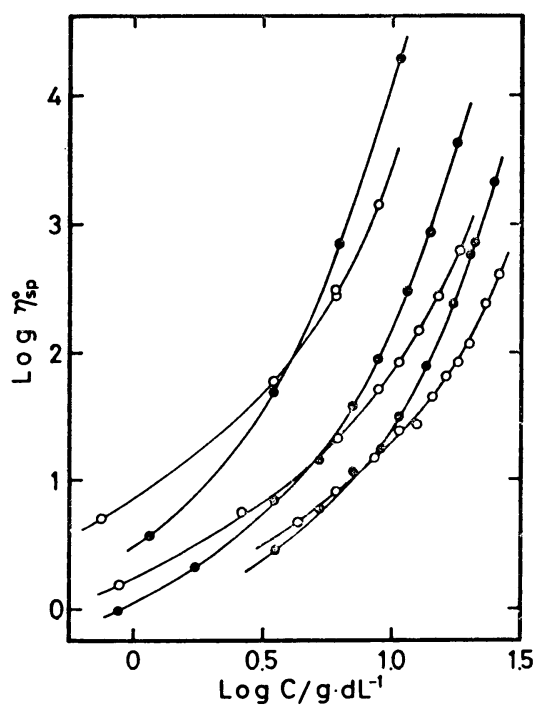

Fig. 14 Comparison between polymer concentration dependences of $\eta_{\mathrm{sp}}{ }^{0}$ in toluene (good solvent) and in $t$-decalin (poor solvent) at $30^{\circ} \mathrm{C} . M_{\mathrm{w}}$ of $\mathrm{P}(\alpha \mathrm{MS}), \quad 1.13 \times 10^{6}, \quad 3.32 \times 10^{5}$ and $1.46 \times 10^{5}$ from top to bottom. (reproduced from ref. 22)

は容易にからみ点が解けるが, 多くのからみ点を解こうとすると 除々に大きなエネルギーを必要とするようになる。

Fig. 14 亿良溶媒中之貧溶媒中の粘度の濃度依存性比較の一例 を示す，濃度の低い希薄溶液中では，粘性係数は高分子コイルの 慣性半径で決まる。慣性半径は良溶媒中の方が高いから, 良溶媒 中の粘性係数が貧溶媒中のそれより高い。しかし, 浱厚溶液中で 
は良溶媒でも貧溶媒でも慣性半径はほぼ非摄動状態にあって殆ど 差はないから，その粘性係数の差はからみの強さによって決まり， 貧溶媒の方が粘性係数が大きい22).

\section{3. 分岐高分子の粘弾性}

分岐高分子には星型，櫛型，ランダム分岐型等いろいろのタイ プがあるが，本研究に主に用いた試料はポリスチレンの幹にポリ スチレンの枝をつけたあのでいわゆる櫛型である(I-6). しかし， 殆どの試料に於て幹分子に比して枝分子の分子量が十分大きいの で，本研究の目的には星型と見なして差し支えない，てのことは 分岐度指数 $g_{\mathrm{s}}\left(\equiv\left\langle S^{2}\right\rangle_{0 \mathrm{~b}} /\left\langle S^{2}\right\rangle_{01}\right.$, 乙てで $\left\langle S^{2}\right\rangle_{0}$ は非摂動平均二乗 慣性半径, 添字 $b$ と $l$ は分岐分子とそれと同じ分子量の線状分子 を示す）が星型として計算した場合と，櫛型として計算した場合 で殆ど差がないととから結論出来る ${ }^{30), 31)}$ 。幹分子と枝分子共に アニオンリビング重合法によって合成し，分子量分布は狭いが, 分子当たりの枝の数は一定ではなく分布をむっている. 研究には， この他に I-5 の方法で合成した 3 本脚の星型ポリ（ $\alpha$-メチルス チレン) 並びに既知の方法で合成した 4 本脚の星型ポリスチレン などあ使用している．分岐高分子の粘性係数のスケーリング則に 基づく整理を Fig. 15 並びに Fig. 16 亿示す ${ }^{322}$. Fig. 16 では少 し差が見られるが，臨界点に関しては線状高分子と分岐高分子の 間には殆ど差がないと考えてよい。乙のととは粘度からみを生ず るセグメントーセグメント相互作用では，線状高分子と分岐高分 子の間で差はないてとを意味している。屯し分子量が十分高く， 高分子コイルが十分に重なり合っていれば，1 分子当たりのから み点の数 $(\mathrm{MC}$ に比例) にも分岐高分子之線状高分子の間に差は ない，従って，濃厚溶液や非希釈系に於ける分岐高分子と線状高 分子の粘弾性挙動の差は, 慣性半径の違いと分岐点が特異性を持 っていれば，それが問題になる．なお，Fig. 15 と Fig. 16 では 準希薄溶液に於ける $\log \left(\eta_{\mathrm{R}}\right)$ vs. $\log \left(C / C^{*}\right)$ あるいは $\log (C[\eta])$ の傾斜が線状高分子と分岐高分子では異なっているが，乙れは $[\eta] \propto M^{a}$ の指数の差によるあのである.

Fig. 17 亿星型に近似出来る分岐高分子の非希釈系におけるず り粘度と分子量の関係を, 線状 PS のデータと比較して示す ${ }^{8), 30)}$. 横軸の分子量の増加は枝分子量が一定ならば，分子当たりの枝の 平均数の増加に対応し，枝の数が一定の場合には枝分子量の増加 に対応する.乙の図の特徴は：(1) 枝分子量一定で枝の数が増加す ると $\eta^{0}$ は増大するが，次第に飽和する傾向を示している．乙の 傾向は枝の数を増加させてあ，慣性半径はそれ程増大しないこと を考えると理解出来る．(2) 分子当たりの枝の数を10本，20本， ……と一定に保ちながら枝分子量を変化させた場合には, $\eta^{0} \propto M^{a}$ の指数 $a$ は線状ポリスチレンの值（３.6）飞比して高い（４.3） ことである.このことは試料が形態的には櫛型であることに起因 するものではなく, 純星型試料でむ同じであるととは Fig. 17 の 二重丸のデータからあ明らかであり，文献 ${ }^{33), 34)}$ とも一致している. 従って, ポリスチレンの場合にあ分岐一定の下で枝分子量を增 大させてゆくと，そのずり粘度は同じ分子量の線状ポリスチレン のずり粘度より大きくなる可能性がある．ポリスチレンより臨界 分子量の小さいポリブタジェンでは更に指数 $a$ 屯高く，また $a$ は 分子量が増加するにつれて大きくなっていて, 粘度の逆転が観察 されているが35) 37)，ポリスチレンの場合には未だ逆転を実験的 に確認出来ていない.

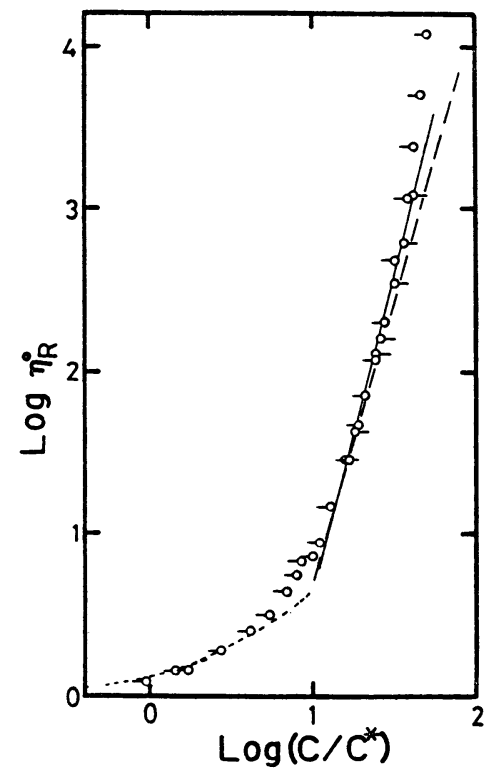

Fig. 15 Double logarithmic plot of $\eta_{\mathrm{R}}{ }^{0}$ and $\left(C / C^{*}\right)$ for three-armed star-shaped $\mathrm{P}(\alpha \mathrm{MS})$ in good solvents $\left(\alpha-\mathrm{CN}\right.$ and toluene). $M_{\mathrm{w}}$ of the samples are 0.90 and $3.60 \times 10^{6}$. The solid line shows the slope predicted from the scaling theory $(a=$ $3.7, \nu=0.585)$. The dotted and broken lines denote the data for linear $\mathrm{P}(\alpha \mathrm{MS})$ in good solvents. (reproduced from ref. 32)

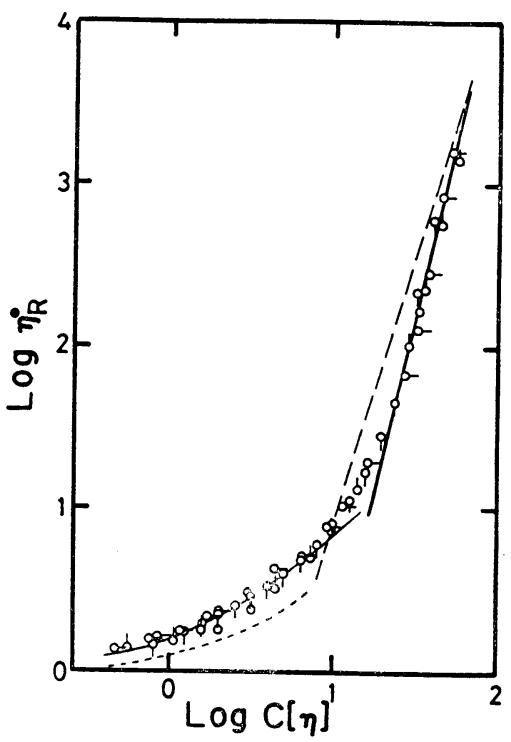

Fig. 16 A scaling plot for steady-flow viscosity of combshaped (nearly star-shaped) PS in good solvents ( $\alpha-\mathrm{CM}$ and toluene). The branch numbers of the samples are 10 13. The thick solid line shows the slope predicted from the scaling theory. The dotted and broken lines show the corresponding data of linear PS in good solvents $(a=4.3, \nu=0.595)$. (reproduced from ref. 32) 


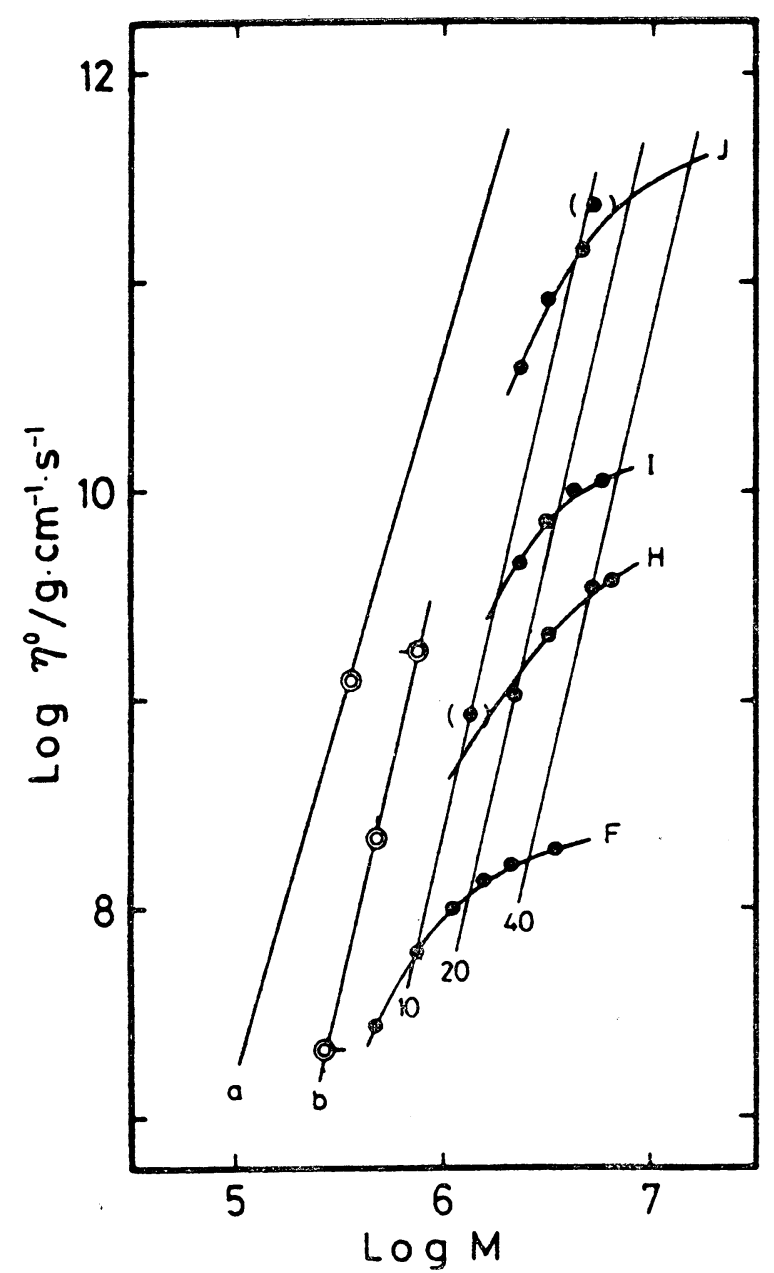

Fig. 17 Molecular weight dependences of steady-flow viscosity $\eta^{0}$ of comb-shaped (nearly star-shaped) and four-armed, star-shaped PS. (a) shows the data of Akovali et al. for linear PS, (b) for fourarmed, star-shaped PS, and others for combshaped PS. $M_{\mathrm{n}}$ of a branch of F, H, I, J samples are $6.5,12.9,17.6,35.8 \times 10^{4}$, while $M_{\mathrm{w}}$ of the parent polymer of those four samples is $9.5 \times 10^{4}$. The numerical figures show the number of branches per molecule. The slopes in $\log \eta^{0}$ vs. $\log M$ plots are all 4.3. (reproduced from 30)

Fig. 17 の分岐高分子の粘度挙動は, 定性的には分岐高分子の 慣性半径の枝分子量, 分岐度依存性によって説明出来るが8), そ れだけでは定量的一致は得られない。なぜ分岐高分子の指数 $a$ が 線状高分子の值より大きくなるかを明らかにすることが, 分岐高 分子のずり粘度の問題点を解決する鍵になるであろう．私はまだ 十分なモデルを掌握していないが，一般に考えられているように 分岐点は粘度的に特異的な性質をむっていて, 通常のからみと巽 なるためであることは間違いないであろう．枝分子の分子量を一 定にして幹分子の分子量を大きくすれば分岐点間相互作用が顕著 になって, 分岐高分子の $\eta_{\mathrm{b}}$ が対応する高分子の $\eta_{1}$ より大きく なることは確認されている (Fig. 18) ${ }^{38)}$.

無限希釈状態における線状高分子の $J_{\mathrm{e}}$ は，高分子コイルが素 抜け状態及び非素抜けの両方の場合に対して, Rouse 及び Zimm

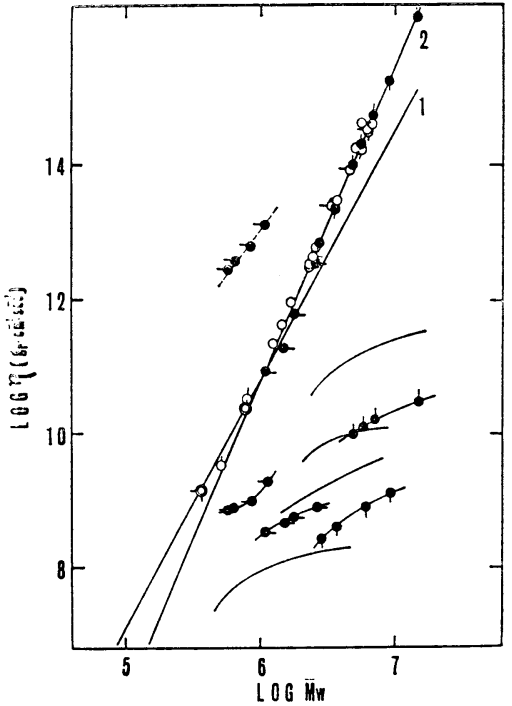

Fig. 18 Molecular weight dependence of $\eta^{0}$ of combshaped PS having short branches (-). $M_{\mathrm{n}}$ of parent polymer is $3.68 \times 10^{5}$, while $M_{\nu}$ of a branch $1.8 \times 10^{4}$. (reproduced from ref. 38 )

によって計算された．その結果は $J_{\mathrm{eR}}=0.4$ (素抜け)，0.206 (非 素抜け) であって, 実験值は非素拔けの理論值に良く一致する ${ }^{39}$. 有限濃度ではあるが, Table I の分類では $D$-領域に入る線状高 分子溶液の研究では, それまでの多くの研究が高分子濃度に殆ど 無関係に $J_{\mathrm{eR}} \simeq 0.4$ を示している ${ }^{40)}$ ．乙の事実はときどき濃度が 高くなると，高分子コイルは素抜けに近づくと説明されているが， 有限濃度に拈ける $J_{\mathrm{eR}}$ の絶対值はあまり意味をあたない，過去の 実験の多くは良溶媒中で行われたが, Rouse-Zimm 理論は非摂 動状態の線状高分子に対し与えられている。 $\theta$ 溶媒 (PS に対し て DOP, P( $\alpha \mathrm{MS})$ に刘しては $n$-undecyl anisitate) 中にて行わ れた実験は $J_{\mathrm{eR}} \simeq 0.7$ を与えている ${ }^{40)}$.

無限希釈で非掑動状態に的る星型高分子の $J_{\mathrm{e}}$ にたいしては, Zimm 及び Kilb の理論があり, 素抜け, 非素抜けの場合につい て理論式が与えられている。乙の場合もまた $J_{\mathrm{eR}}$ が濃度によらな いで一定值を示す実験事実は意味があるが, 有限濃度で, 特に良 溶媒中行でわれた実験值の絶対值に意味があるとは思われない. しかし, 線状高分子に対する Rouse-Zimm 理論と星型高分子に 対するZimm-Kilb の理論は, 同じモデルに基づいているから両 者の比 $g_{\mathrm{J}}$ は, 溶媒にも温度にもそして濃度にも無関係と仮定し て差し支えないと考えている.

$$
\left(J_{\mathrm{eR}}\right)_{\mathrm{b}}=\left(J_{\mathrm{eR}}\right)_{1} \cdot g_{\mathrm{J}}
$$

ここで, 添字 $l$ 及び $b$ は線状と星型高分子を表す. $g_{\mathrm{J}}$ の計算值は,

$$
\begin{array}{ll}
g_{\mathrm{J}}=(15 f-14) /(3 f-2)^{2} & \text { (素抜け) } \\
g_{\mathrm{J}}=(31.8 f-28.2) /(3.90 f-19.4)^{2} & \text { (非素抜け) }
\end{array}
$$

である. $f$ は分岐度であり, $f=3$ に対しては $g_{\mathrm{J}}$ は素拢けの場 合屯非素拔けの場合屯殆ど同一 $(0.7$ 及び 0.61$)$ を与える. 平均 值 0.65 は 3 本脚星型 $\mathrm{P}(\alpha \mathrm{MS})\left(M_{\mathrm{w}}=0.87\right.$ 及び $\left.3.57 \times 10^{6}\right)$ を用 いた実験結果と良い一致を示している ${ }^{40)}$.

とにかく $\theta$ 溶媒にせよ良溶媒にせよ, 素抜けであるか非素抜け であるかは別にして， $D$-領域の高分子コイルの $J_{\mathrm{e}}$ は分岐高分子 の方が同一分子量の線状高分子の值より屯小さくなることは確か 


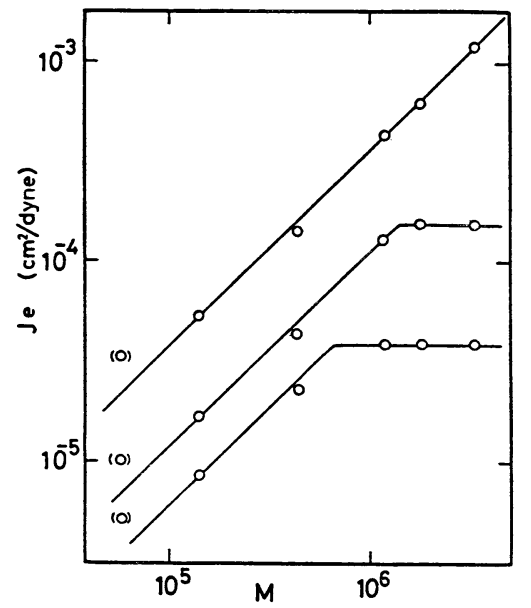

Fig. 19 Molecular weight dependence of steady-state compliance $J_{\mathrm{e}}$ of $\mathrm{P}(\alpha \mathrm{MS})$ in $\alpha$-chloronaphthalene. Polymer concn., $0.030,0.100$ and $0.200 \mathrm{~g} / \mathrm{ml}$ from top to bottom. Parentheses denote the data of a sample which has a little different tacticity. (reproduced from ref. 20)

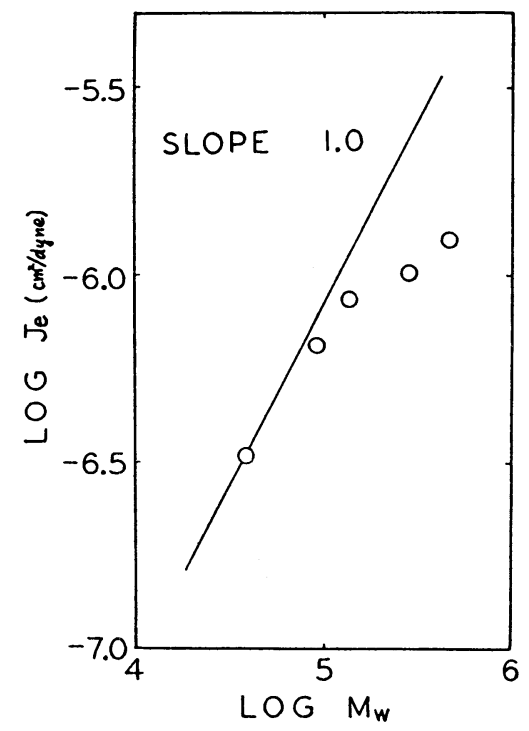

Fig. 20 Molecular weight dependence of $J_{\mathrm{e}}$ of $\mathrm{P}(\alpha \mathrm{MS})$ at the undiluted state. (reproduced from ref. 42)

である.一方，フィルムを用いた応力緩和実験などから決定した 非希釈状態の分岐高分子の $J_{\mathrm{e}}$ は, 同じ分子量の線状高分子の値 よりあ大きくなるととが実験的確認されている。なお，ての研 究では $J_{\mathrm{e}}$ の测定には無希橎状態では応力緩和が用いられ，溶液 状態では Weissenberg レオゴニオメーターが用いられた。この 両者の測定結果には全く矛盾がなく, 後者の方法で決定した溶液 の $J_{\mathrm{e}}$ を溶媒濃度零まで外挿すれば前者の值に一致する20),21),31).

分子量が小さく, 分子間に有効なからみが生成しなければ, 非 希釈系であっても，孤立高分子鎖の $J_{\mathrm{e}}\left(J_{\mathrm{e}} \propto M / C\right)$ が観察され るが, 分子量が大きくなって, 分子間に十分からみが形成されれ ばその弾性はからみ点間分子量によって決まるから，Jeは分子 量に無関係になる. Fig. 19 と Fig. 20 亿その例を示そう. Fig. 19 は線状ポリ（ $\alpha$-メチルスチレン）濃厚液溶のデータ ${ }^{20)}$, Fig. 20

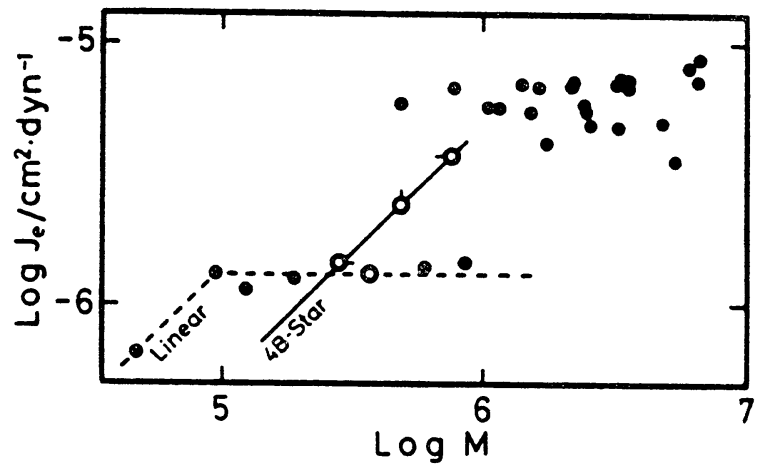

Fig. 21 Comparison between $J_{\mathrm{e}}$ of linear and star-shaped PS at the undiluted state. Filled circles show the data of comb-shaped (nearly star-shaped) PS at the undliuted state. Solid line "Linear" shows the data for linear PS by Plazek et al. (reproduced from ref. 30)

は同じく線状ポリ ( $\alpha$ ーメチルスチレン) の非希釈系のデータ ${ }^{42)}$ ある．Fig. 5 の $J_{\mathrm{e}}$ に対する実線を無溶媒系まで外挿すれば，高 分子固体中に扎いて 孤立鎖挙動が観察される 臨界分子量 $M_{\mathrm{c}}^{\mathrm{J}}$ を 決定出来る. この $M_{\mathrm{c}} \mathrm{J}$ は粘度に於ける臨界分子量 $M_{\mathrm{c}}{ }^{\eta}$ よりか なり大きく， $J_{\mathrm{e}}$ の孤立鎖挙動はかなり広い範囲で観察される. ポリスチレン，ポリ ( $\alpha$-メチルスチレン) の場合 $M_{\mathrm{c}}{ }^{\eta} \simeq 2 \times 10^{4}$, $\left.M_{\mathrm{c}}^{\mathrm{J}} \simeq 10 \times 10^{4}\right)$ である. 分子量が大きくなると $J_{\mathrm{e}}$ は分子量に無 関係に一定になるのは, 鎖状高分子に共通して見られる現象之思 うが，必ずしも十分には確認されていない，その理由としては， 孤立鎖 $J_{\mathrm{e}}$ 従って孤立鎖挙動加ららみ域挙動への転移は非常に 高次の分子量に支配されるので39), この種の実験には十分に分子 量分布の狭い試料を用いる必要があるためと考えている.

Fig. 21 には非希釈状態に於ける線状高分子之, 分岐高分子の $J_{\mathrm{e}}$ の分子量依存性を比較する ${ }^{30)}$. 分子量が小さければ, 星型高 分子であ $J_{\mathrm{e}} \propto M / C$ ( $C$ は一定) であるととを示している. 残念 ながら 4 本脚の星型高分子の枝分子量を十分飞高くして，孤立鎖 偅卖からからみ域挙動への転移を観察するととは出来なかった。 一方, 櫛型高分子の場合には, $J_{\mathrm{e}}$ は分子量に無関係になること が観察されるが，この場合には逆に星型近似を維持したまま櫛型 高分子の枝分子量を下げて, 孤立鎖挙動へ移行することを観察す るととは出来なかった. それにも拘らず総合すれば, 分岐高分子 であ枝分子量が大きくなれば孤立鎖挙動からからみ域挙動への転 移はあると見てよいであろう. 問題はからみ域に於て分岐高分子 の $J_{\mathrm{e}}$ が, Fig. 21 に比較のために示してある対応する線状高分 子の值よりも大きいてとである.

Fig. 22 飞 4 本脚星型 PS の $J_{\mathrm{e}}$ の濃度依存性を線状 PS の データと比較する ${ }^{31)}$. 星型高分子の場合には分子量がかなり高い にも拘らず，無溶媒系に達してもなおからみ域に入らないととを 見るととが出来る. Fig. 23-B に同じデータを $J_{\mathrm{eR}}$ vs. CM の 両対数の形に再プロットして示す ${ }^{21)}$, Fig. 23-A は分岐度の大き い櫛型高分子に対する同様のプロットである，からみ点を形成し はじめる臨界 $\mathrm{CM}$ 值は, 分岐高分子の場合には線状高分子の場 合よりあはるかに大きいととは明らかである，結果として，同じ 分子量, 同じ濃度, たとえば無溶媒系で比較すれば分岐高分子の $J_{\mathrm{e}}$ が, 線状高分子の值よりあ大きくなるととは理解出来る. 


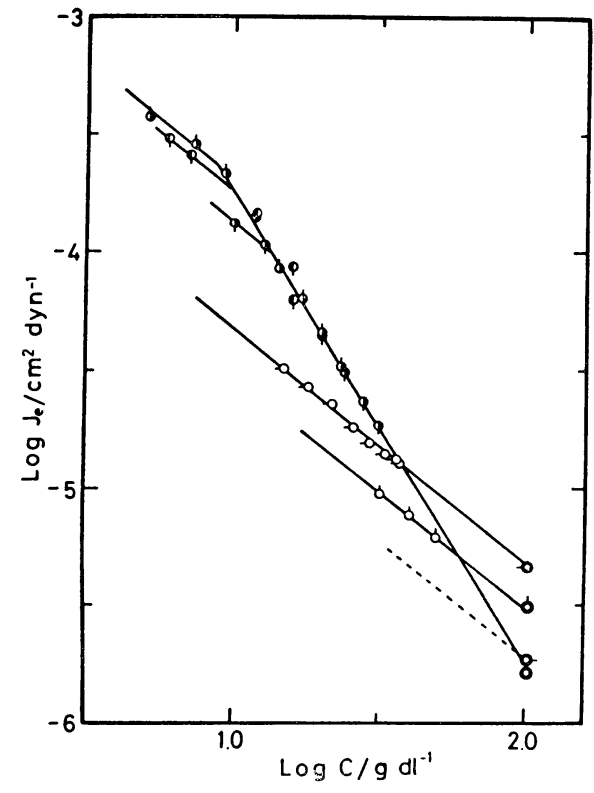

Fig. 22 Polymer concentration dependence of $J_{\mathrm{e}}$ of fourarmed, star-shaped PS in comparison with that of linear PS. Symbols (@) with pip-left, up and right show the data for four-armed, star-shaped PS $\left(M_{\mathrm{n}}=7.50,4.88,2.80 \times 10^{5}\right)$, while (○) without pip shows the value for undiluted linear $P S$ with $M_{\mathrm{w}}=3.68 \times 10^{5}$. Open circles with pip show the data of the star-shaped PS in $\alpha$ chloronaphthalene. Other symbols"show the data for linear PS in good and $\theta$ solvents (see ref. 31). (reproduced from ref. 31)

粘度が希薄溶液から準希薄溶液へ移行する臨界の $C / C^{*}$ 值は分 岐によってそれ程変わらないが， $J_{\mathrm{e}}$ の場合には孤立鎖挙動から からみ域挙動への移行は分岐によって大きく変化する. ての理由 は必ずしもはっきりしないが, 線状高分子と分岐高分子の慣性半 径の差之全体の分子量のか悋合いによると考えている．系全体が 疑網状構造をとるためには, 高分子コイルが十分重なり合わなけ ればならないととは線状高分子のデータから明らかであるが, 分 岐高分子の場合には分岐度を增せば增す程この要求を満たすとと が困難になる。

\section{4. おわりに}

以上は, 私が名古屋大学工学部在職中に藤本輝雄氏や大学院後 期過程の学生諸君を中心に, 多くの学生諸君の協力を得て行われ た研究を, 私の立場から二項目に限ってま之めてみたものである. 直接粘弾性研究に関係した方々の他に, 試料のキャラクタリゼー ションを行った方々の貢献む大きい. 関係した学生諸君の数はも ち万ん, 中心になって研究された方々の数む多すぎて, こてにい ちいち名前をあげて謝辞を述べるわけにあいかないが，関係され た名古屋大学の教職員並びに学生諸君に厚く御礼申し上げます. また，取り上げた項目む上述の二項目だけでは片寄りすぎている. レオロジー研究をはじめて最初に藤本輝雄氏が行った「単分散ポ リ $(\alpha$-メチルスチレン $)$ の応力緩和」42)はよく文献として引用さ れているが，それに緩和スペクトルの分子量依存性の研究43)なよ゙ は現在豊田工大における仕事の布石になっている。 また, 故山本

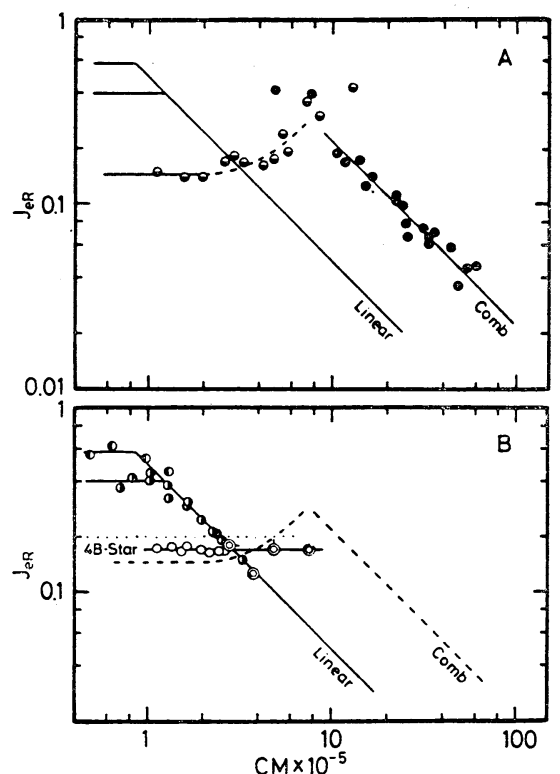

Fig. 23 Double-logarithmic plots of $J_{\mathrm{eR}}$ vs $C M$. (A) Half-filed and filled circles show the data of comb-shaped (nearly star-shaped) PS in DOP (nearly $\theta$ ) and at the undiluted state, respectively. (B) The data are the same as in Fig. 22. Symbols right-filled and left-filled circles show the data for linear PS in good $(\alpha-\mathrm{CN})$ and nearly $\theta$ (DOP) solvents, respectively, while double-circle shows the data of linear PS at the undiluted state. Open circles and double-circles with pip show the data of four-armed, starshaped PS in good solvent $(\alpha-\mathrm{CN})$ and at the undiluted state, respectively. The broken line "Comb" is the same as in (A). (reproduced from ref. 31)

三三三教授の思い出の残る「構成方程式の実験的検討 $\lrcorner^{44) \sim 48)}$, あ るいは私自身が特に関心をもっている「高分子電解質溶液の粘弾 性」49）などあ別の機会にまとめてみたい。

また，本研究に関連して内外の多くのすぐれた研究がある．当 然てれらあ引用すべきであるが，時間的制約のため割愛せざるを 得なかった。必要の場合，私共の原報を参考にしていただくこと で打許し願いたい。

\section{文献}

1) Fujimoto, T., N. Ozaki, and M. Nagasawa, J. Polym. Sci. Part A, 3, 2259 (1965).

2) Fujimoto, T., and M. Nagasawa, Polym. J., 7, 397 (1975).

3) Kitano, T., T. Fujimoto, and M. Nagasawa, Macromolecules, 7, 719 (1974).

4) Kitano, T., M. Mitsumura, T. Fujimoto, and M. Nagasawa, Macromolecules, 8, 382 (1975).

5) Kitano, T., T. Fujimoto, and M. Nagasawa, Polym. J., 9, 153 (1977).

6) Higo, Y., H. Chōshi, T. Fujimoto, and M. Nagasawa, Polym. J., 12, 729 (1980).

7) Fujimoto, T., S. Tani, K. Takano, M. Ogawa, and M. 
Nagasawa, Macromolecules, 11, 673 (1978).

8) Fujimoto, T., H. Narukawa, and M. Nagasawa, Macromolecules, 3, 57 (1970).

9) Matsushita, Y., H. Chōshi, T. Fujimoto, and M. Nagasawa, Macromolecules, 13, 1053 (1980).

10) Matsushita, Y., K. Yamada, T. Hattori, T. Fujimoto, Y. Sawada, M. Nagasawa, and C. Matsui, Macromolecules, 16, 10 (1980).

11) Fujimoto, T., K. Ohkoshi, Y. Miyaki, and M. Nagasawa, Science, 224, 74 (1984).

12) Matsushita, Y., H. Furuhashi, H. Chōshi, I. Noda, M. Nagasawa, T. Fujimoto, and C.C. Han, Polym, J., 14, 489 (1982).

13) Ohtani, H., S. Tsuge, Y. Matsushita, and M. Nagasawa, Polym. J., 14, 495 (1982); 16, 727 (1984).

14) Matsushita, Y., Y. Nakano, R. Saguchi, H. Chōshi, and M. Nagasawa, Polym. J., 18, 361 (1986).

16) de Gennes, P.-G., "Scaling Concepts in Polymer Phy. sics", Cornell Univ. Press, Ithaca, N.Y. (1979).

17) Noda, I., "Applicability of the Scaling Concept to Thermodynamic and Viscoelastic Properties of Polymor Solutions" in "Molecular Conformation and Dynamics of Macromolecules in Condensed Systems", ed. M. Nagasawa, Elsevier, Amsterdam (1988).

18) Noda, I., N. Kato, T. Kitano, and M. Nagasawa, Macromolecules, 14, 668 (1981).

19) Takahashi, Y., Y. Isono, I. Noda, and M. Nagasawa, Macromolecules, 18, 1002 (1985).

20) Sakai, M., T. Fujimoto, and M. Nagasawa, Macromolecules, 5, 786 (1972).

21) Takahashi, Y., I. Noda, and M, Nagasawa, Macromolecules, 18, 2220 (1985).

22) Isono, Y., and M. Nagasawa, Macromolecules, 13, 862 (1980).

23) Endo, H., T. Fujimoto, and M. Nagasawa, J. Polymer Sci. A-2, 9, 345 (1971).

24) Greassley, W.W., J. Chem. Phys., 43, 2696 (1965) ; 47, 1942 (1967).

25) Takahashi, Y., Y. Isono, I. Noda, and M. Nagasawa, Macromolecules, 20, 153 (1987).

26）山本三三三, “物体の変形学”, 誠文堂, 東京 (1972).

27) Lodge, S.A., "Elastic Liquids”, Academic Press, New York-London (1964).

28) Sakai, M., H. Fukaya, and M. Nagasawa, Trans. Soc.
Rheology, 16:4, 635 (1972).

29) Kajiura, H., M. Sakai, and M. Nagasawa, Trans. Soc. Rheology, 20:4, 575 (1976).

29-a）倉内, 川浦, 志鶴, 五十野, 藤本, 高分子学会年次大会, 神奈川大（横浜）(1989年 5 月).

30) Isono, Y., T. Fujimoto, H. Inagaki, M. Shishido \& M. Nagasawa, Polym. J., 12, 131 (1980).

31) Isono, Y., T. Fujimoto, H. Kajiura, and M. Nagasawa, Polym. J., 12, 369 (1980).

32) Takahashi, Y., F. Suzuki, M. Miyachi, I. Noda \& M. Nagasawa, Polym. J., 18, 89 (1986).

33) Masuda, T., Y. Ohta, and S. Onogi, Macromolecules, 4, 763 (1971).

34) Utracki, L.A., and J.E.L. Roovers, Macromolemolecules, 6, 366 (1973).

35) Kraus, G., and T. Gruver, J. Polym. Sci., A-3, 105 (1965) ; J. Polym. Sci. Polym. Phys. Ed., 8, 305 (1970).

36) Greassley, W.W., T. Masuda. J.E.L. Roovers, and N. Hadjichristidis, Macromolecules, 9, 127 (1976).

37) Greassley, W.W., and J, Roovers, Macromolecules, 12, 959 (1979).

38) Fujimoto, T., H. Kajiura, H. Hirose, and M. Nagasawa, Polym. J., 3, 181 (1972).

39) Ferry, J.D., "Viscoelastic Properties of Polymers", Wiley, New York, N.Y. (1970).

40) Kajiura, H., Y. Ushiyama, T. Fujimoto, and M. Nagasawa, Macromolecules, 11, 894 (1978).

41) Zimm, B.H., and R.W. Kilb, J. Polym. Sci., 37, 19(1959).

42) Fujimoto, T., N. Ozaki, and M. Nagasawa, J. Polym. Sci. A-2, 6, 129 (1968).

43) Isono, Y., T. Fujimoto, N. Takeno, H. Kajiura, and M. Nagasawa, Macromolecules, 11, 888 (1978).

44) Endo, H., and M. Nagasawa, J. Polym. Sci. A-2, 8, 371 (1970).

45) Kajiura, H., H. Endo, and M. Nagasawa, J. Polym. Sci. Polym. Phys. Ed., 11, 2371 (1973).

46) Sakai, M., H. Kajiura, and M. Nagasawa, Trans. Soc. Rheology, 18:2, 323 (1974).

47) Isono, Y., H. Kajiura, and M. Nagasawa, J. Rheology, 23(1), 79 (1979).

48) Takahashi, Y., Y. Isono, I. Noda, and M. Nagasawa, Macromolecules, 19, 1217 (1986).

49) Sakai, M., I. Noda, and M. Nagasawa, J. Polym. Sci. A-2, 10, 1047 (1972). 